\title{
Sciendo
}

DOI: 10.2478/orga-2020-0014

\section{Construction and Significance of Corporate Social Responsibility Indices - from Results to the Essence}

\author{
Dana BERNARDOVÁ ${ }^{1}$, Klára KAŠPAROVÁ ${ }^{2}$, Martin FINK ${ }^{1}$, \\ Kateřina IVANOVÁ ${ }^{1}$ \& Tetiana ARKHANGELSKA ${ }^{1}$
}

\begin{abstract}
${ }^{1}$ Moravian Business College Olomouc, Department of Social Science and Law, tř. Kosmonautů 1288/1, 779 00 Olomouc, Czech Republic, dana.bernardova@mvso.cz, martin.fink@mvso.cz, katerina.ivanova@mvso.cz, tetiana.arkhangelska@mvso.cz

${ }^{2}$ Masaryk University, Faculty of Economics and Administration - Department of Corporate Economy, Lipová 507/41a, 60200 Brno, Czech Republic, klara.kasparova@econ.muni.cz
\end{abstract}

\begin{abstract}
Background and Purpose: Regular reporting on Corporate Social Responsibility (hereinafter referred to as CSR) should make it easier for enterprises to identify the sustainability risks and lead to an increased investors and consumers' confidence. The aim of the paper is to find out how the indices which evaluate the socially responsible behaviour of enterprises are constructed.

Design/Methodology/Approach: The scoping review is the method used in this study. The scoping question is: What do we know about the construction of indices evaluating the socially responsible behaviour of organisations from the existing expert resources?

Results: The analysis of 20 papers shows that there is no consensus about the method of determining the weights and constructing the index. There are 4 approaches to the aggregated index construction. The first one uses the percentage of filling the specific criteria or the average of values of specific dimensions of the index. The second one uses the multi-criteria decision-making methods (most often the Analytical hierarchical process method). The third one uses unconventional linguistic models and fuzzy logic and finally, the fourth one uses the factor analysis or the method of the main components.

Conclusion: The main feature of CSR indices lies in their methodological disunity. It complicates the understanding of the CSR outputs and essentially makes it impossible to create a CSR performance ranking, especially for small and medium-sized enterprises (hereinafter referred to as SMEs).
\end{abstract}

Keywords: Corporate Social Responsibility, Index, SMEs, Scoping review, Clarity of CSR index outputs

\section{Introduction}

Corporate social responsibility of enterprises (hereinafter referred to as CSR) is interpreted as a transition of enterprises in the perception of their role from the level "profit only" to the level of three "P" - "profit, people, and planet". CSR is also interpreted as the Triple bottom line (TBL). The term TBL, formulated by Elkington in 1994, means that companies should focus not only on increasing their added value in the economic field, but also in the environmental and social area (Elkington, 2013). CSR is connected to ethics, i.e. the ethical dimension of entrepreneurship. It is also related to economics of enterprises, organisation management, and public interests (Slaper \& Hall, 2011; Pokorná, 2012; UN, 2013).

The strategy Europe 2020 was adopted in 2010. Its main issue is the promotion of social and territorial cohesion and sustainable growth (European Commission, 2009). In response, the European Commission issued the Communication on 'A Renewed EU Strategy 2011-14 for

Received: 11th July 2019; revised: 29th March 2020; accepted: 8th July 2020 
Corporate Social Responsibility'. It deals with a newly defined responsibility of enterprises for their impact on the society (European Commision, 2011). The Council of Europe called for the same in March 2016. At present, the Directive 2014/95/EU (European Parliament, 2014) the European Parliament and of the Council on non-financial reporting by large enterprises obliges them to regularly provide non-financial information on their activities. It applies to trading companies with over 500 employees, with a balance sheet total of more than EUR 20 million and the net profit of more than EUR 40 million. Approximately 30 organisations will be affected by this measure in the Czech Republic according to the assumptions. Regular reporting should make it easier for enterprises to identify the sustainability risks and lead to an increased investors and consumers' confidence. Obviously, the socially responsible reporting has an impact on the successful corporate operations of large and medium sized organisations conduct (Peršič \& Markič, 2013). However, the Directive does not prevent the Member States from requiring the disclosure of non-financial information from enterprises not covered by this Directive, including SMEs.

In order to trustworthily report on CSR, there exist the measurement and implementation methodologies. The resulting reports and methodologies are becoming important in the development and spreading the CSR ideas (Fink et al., 2020). Methodologies by Leipziger (2003) considers these methodologies the CSR standards and, according to him, they can be divided into "... performance and process-oriented standards". Performance oriented standards can be considered normative standards as they "define only minimum standards of what the socially responsible behaviour is" (Leipziger, 2003, p. 39). The performance-oriented standards group can include methodologies measuring the socially responsible performance of enterprises generally called the CSR indices.

In general, the index is intended to quickly navigate large data files (lists of companies, databases of individual organisations, etc.). A specific index expresses belonging to a group of organisations holding the given index. In this case, indices can be considered face values. Within a single group (index as a number), we can consider not only nominal but also ordinal data, i.e. we can create an order of organisations grouped under the given index. Cardinal data have the highest informative value, showing how much a particular organisation is better than the following one in the ranking. This is ideal when evaluating the CSR level of organisations, as organisations that hold a particular CSR index should be able to determine their CSR rate compared to other indexed organisations. For example, the DJSI index (Dow Jones Sustainability Index) publishes the cardinal data (Industry Leader Report, 2018) in publicly accessible materials, compared to the FTSE4Good Index Series, where we were not able to trace such data in publicly accessible sources.
The initial study was conducted by the authors. Being a mega-source of scientific information for social and humanitarian sciences, the EBSCO database was chosen for the search of literary resources. The keywords for the search strategy were determined according to the PCC algorithm. The keywords were: Index or Indices and CSR. The search strategy was also specified: not to search for keywords in full texts, but only in the titles or abstracts; to use the available keyword equivalents; to search only in the reviewed texts. The final result was 50 texts, all of which discussed the issue of CSR, but only 12 of them mentioned the keyword index in the abstract. The same keywords were also searched for in the Google Scholar database, which offered over 100,000 links. The Social Responsibility Journal, which includes most of the keywords according to this database, was selected. According to the best correspondence between the keywords and the paper title, four more research papers from this journal were selected.

On the basis of our initial study, we can conclude that the indices mainly reflect the activities perceived as CSR in combination with the economic parameters and interests of financial institutions (profitability, market potential, stability of the stock market position, etc.) and serve as a guidance for potential investors (Pinilos et al., 2018; Hawn et al., 2018). Their benefit indicating the socially responsible behaviour is small and the impacts of CSR indices on the ethical behaviour and culture of the society are unconvincing (see Adel et al., 2019; Collison et al., 2009).

Not every organisation can reach the point of having the CSR index, and according to the found-out indications, it is a fairly small group of large organisations. With all respect to the 'Strategy 2020', indices must be suitable for all types of organisations at all the regional levels as there are more than $90 \%$ of SMEs (United Nations, 2019) in the world. Measuring the organisations' performance in CSR (if it does have a use value for their recipients - stakeholders) must be comprehensible to them and the results of the organisations' indexation must be comparable (as pointed out by Rita et al., 2018 and Yang Wen-Tao et al., 2016).

None of the authors of the initial study mentions the existence of a universal and comprehensible CSR index suitable for all types of organisations and stakeholders covering all the CSR areas and based on the CSR ethical foundations. Adel et al. (2019) (attempting to construct such an index) mention the trend of the need for a new CSR index that outlines the evolving needs and requirements of CSR in a non-financial ethical dimension.

From the point of view of ethical entrepreneurship and thus sustainability, it can be deduced that CSR indices should be constructed to serve not only financial institutions, but also all the external stakeholders, organisations of all types and their internal stakeholders (Government of the Czech Republic, 2017). 
The aim of the paper is to find out how the indices that evaluate the socially responsible behaviour of organisations are created.

\section{Methodology}

The method of secondary research (i.e. the analysis of already identified and published results) aimed at a rapid systematic review of the selected topic - scoping review was chosen. Its purpose is to describe the scope of the already published scientific results on the subject (Peters et al., 2015). To conduct the scoping review, the Arksey and O'Malley approach, which consists of five steps: identifying search issues, identifying relevant research, selecting research, collecting and comparing data, and summarising and reporting on results was chosen (Arksey \& O'Malley, 2005).

The first step in the procedure proposed by Arksey and O'Malley is formulation of the study (scoping) question (Arksey \& O'Malley, 2005). The general study (scoping) question is: "What do we know about the construction of indices evaluating the socially responsible behaviour of organisations from the existing expert resources?" The second step in the scoping review method is to determine the descriptive criteria of the scientific papers, see Table 1. The third step is to determine the specific criteria for the initial study of the content of scientific papers on the basis of the initial research. Table 1 shows the second and third steps of the scoping review. The results are presented according to these criteria.

Table 1: Descriptive and specific criteria established for the scoping review method

\begin{tabular}{|l|l|}
\hline Descriptive criteria & Specific criteria \\
\hline Publication year & $\begin{array}{l}\text { 1. The method of determining dimensions and (sub)catego- } \\
\text { ries (terms dimension and subcategory are chosen for being } \\
\text { the most common in terms of the issue) }\end{array}$ \\
\hline Authors & $\begin{array}{l}\text { 2. The method of the index model validation (used for the } \\
\text { index construction) }\end{array}$ \\
\hline & 3. The method of determining the weights ${ }^{1}$ \\
\hline Research area & 4. The data collection method (filling the index with data) \\
\hline Journal title & 5. The method of index construction \\
\hline
\end{tabular}

Source: authors

The Scopus database was selected to perform the scoping review. The Scopus database contains more papers on the issue of CSR indices than the Web of Science database, its sources are quoted more often (Harzing \& Alakangas, 2016). The papers in the Scopus database target at a wider target group than the academic community (Chadegani et al., 2013), which is suitable for the applied scientific issue of the CSR indices. Only papers in English professional journals on Business, Management and Accounting for the last 5 years (i.e. from 2014 to 2018) were searched. The next step was to formulate the keywords for the search. The following procedure was selected to search for synonyms for the expression "CSR index". Two expressions were entered into the search algorithm - "CSR" and "index" (they had to appear together). Subsequently, the entire generated list of papers was reviewed, and the synonyms were generated based on their titles. The occurrence of the keywords was monitored only in the paper titles, keywords, and abstracts. The papers not addressing indices evaluating the general concept of CSR were excluded from the search, only the papers meeting the specific crite- ria were left. The search order was created using Boolean operators.

The search order using Boolean operators was:

TITLE-ABS-KEY ( "social responsib* index" OR "tool to measure social responsib*" OR "evaluate social responsib*" OR "evaluation of social responsib*" OR "sustainability index" OR "tool to measure sustainability" OR "evaluate sustainability" OR "evaluate of evaluation of evaluation of sustainability" AND NOT REPORTING AND NOT DISCLOSURE ) AND DOCTYPE ( AR OR RE ) AND ( LIMIT-TO ( SRCTYPE, “j “) AND ( LIMIT-TO ( SUBJAREA, "BUSI “) OR LIMIT-TO ( SUBJAREA, "English “) OR LIMIT-TO ( PUBYEAR, 2015 )

A total of 130 papers were obtained through the carried out above procedure. Based on the study of the title and abstract, their relevance to the study question was assessed. Only those papers that met the following conditions were selected:

1. They focused at least partially on the methodology of the CSR index construction.

${ }^{1}$ IAEP, School Children's Acquisition and Maintenance of Quantitative Thinking in Mathematics, PISA, TIMSS. 
2. The papers related to the general concept of CSR (or possibly the parallel and very close concept of permanent sustainability) or at least two of the three dimensions of the concept TBL. The papers focusing on a narrow segment - region, sector, product, or raw material were excluded.

3. The full text of the paper was available.

As a result of the application of these selective criteria, 20 papers were analysed - see Table 2 .

\section{Results}

The results are divided into two parts according to the types of the set criteria (see Table 1). The first part presents the descriptive information on the obtained resources. The second part presents the specific information relating to the content of the obtained resources.

Analysis according to the descriptive criteria - descriptive information about the obtained sources.

The scoping review shows that the interest in constructing the index measuring the socially responsible behaviour of an organisation or its sustainability is gradually increasing in the analysed period, especially since 2016 see Figure 1. However, the interest is still very small in terms of absolute numbers.

Various authors deal with the issue, however, neither of them is listed in more than one paper. ${ }^{2}$

Graph 2 shows that the papers address the issues of Business, Management, and Accounting most frequently. Further, they address Engineering, Environmental Science, and Energy.

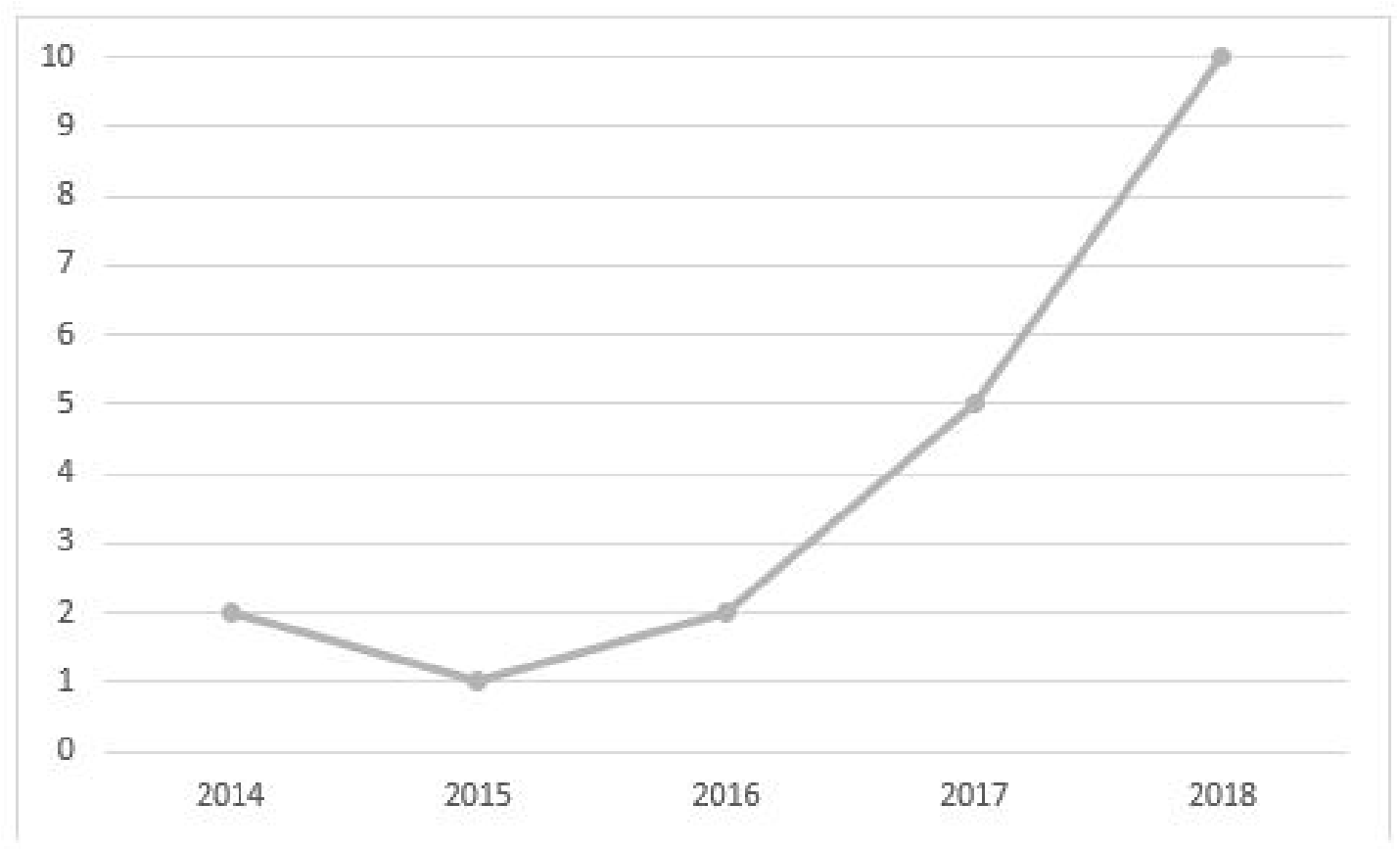

Source: authors, based on data from the Scopus database ('Scopus’ 2018)

Figure 1: Number of papers published in the Scopus database for the period 2014-2018

\footnotetext{
${ }^{2}$ Two authors have the same surname (Ribeiro), but their names show that they are two different people. The data in the Scopus database show that they do not even come from the same workplace. The authors from the USA, Brazil, and (a little less) from the Czech Republic are most concerned with the issue. Two collectives of authors from the Czech Republic deal with the issue. The first are Staňková and Zapletal from the Faculty of Economics of the Technical University of Ostrava. What is interesting about their approach is that they use unconventional linguistic models and fuzzy logic to construct the index - see below. The second team consists of Rajnoha, Lesníková, and Krajčík - all the three authors work in different universities in the Czech Republic.
} 


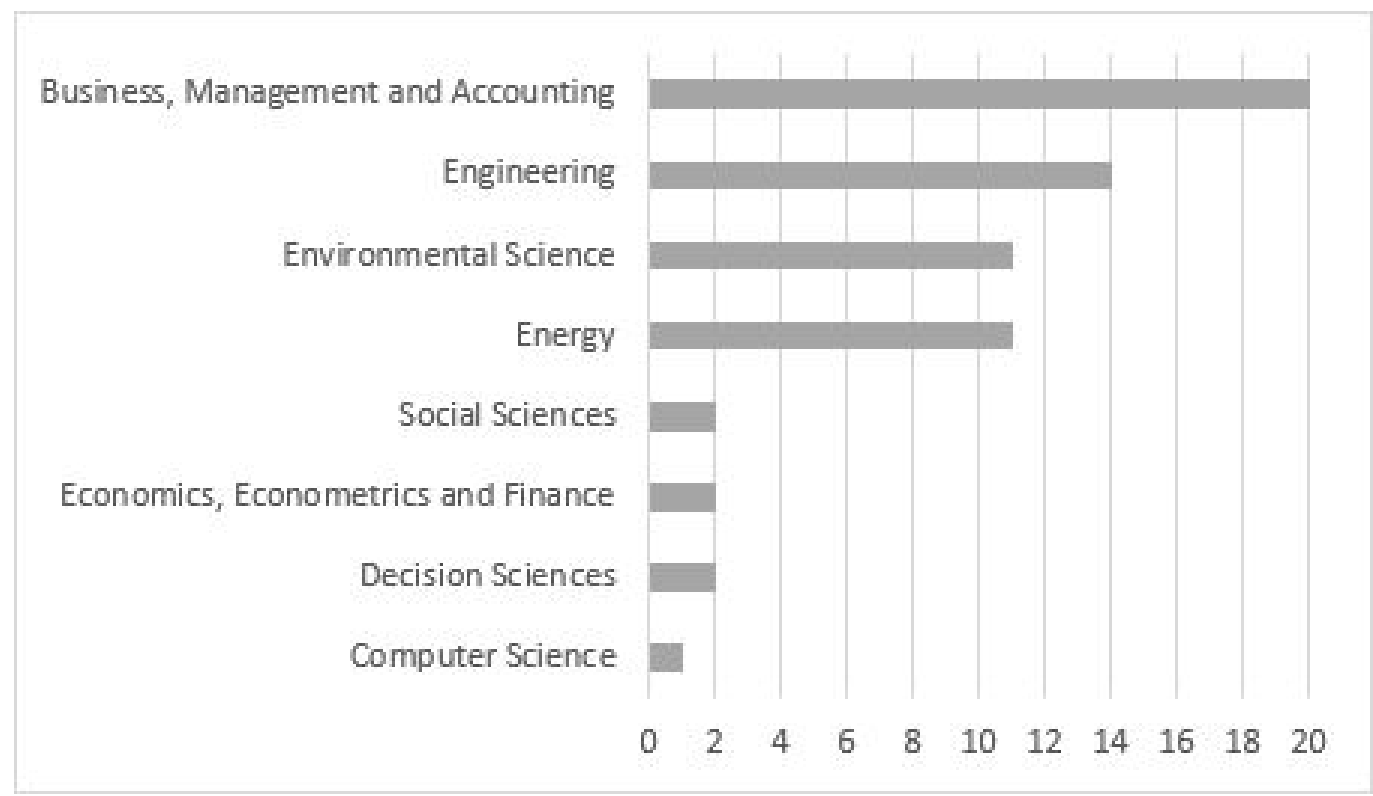

Source: authors, based on data from the Scopus database ('Scopus' 2018)

Figure 2: Connection of the examined papers to the research area ${ }^{3}$

Data from the Scopus database show that the papers on the index construction are concentrated in the Journal of Cleaner Production by the Elsevier publishing house, the Cite Score of which was 5.79 last year, SCImago Journal Rank $(1,467)$ and Source Normalized Impact per Paper $(2,194)$. The number of such papers in the Journal of Cleaner Production is increasing - in 2014 and 2016 there appeared only 1 paper on the subject, in 2017 there were already 2 papers, and in 2018 there were already 7 papers in its different issues. Beyond them, the rest of the papers can be found in other journals. As for the Czech journals, they are $\mathrm{E}$ and $\mathrm{M}$ : Economics and Management ${ }^{4}$ and Scientific Papers of the University of Pardubice, Series D: Faculty of Economics and Administration. ${ }^{5}$

Analysis according to the specific criteria - specific information related to the content of the obtained sources.

Table 2: Results of the analysis of the content of papers according to the specific criteria

\begin{tabular}{|c|c|c|c|c|}
\hline Author & $\begin{array}{l}\text { Criterion 1: } \\
\text { the method of } \\
\text { determining } \\
\text { dimensions } \\
\text { and (sub) } \\
\text { categories }\end{array}$ & $\begin{array}{l}\text { Criterion 2: } \\
\text { the method of index } \\
\text { model validation }\end{array}$ & $\begin{array}{l}\text { Criterion 4: the meth- } \\
\text { od of data collection } \\
\text { for filling the index } \\
\text { with data }\end{array}$ & $\begin{array}{l}\text { Criterion 5: the } \\
\text { method of the } \\
\text { index construc- } \\
\text { tion }\end{array}$ \\
\hline Ribeiro et al., 2018 & $\begin{array}{c}\text { review, } \\
\text { dimensions } \\
\text { established } \\
\text { without further } \\
\text { explanation }\end{array}$ & tested in 2 cities & secondary data & simple index \\
\hline $\begin{array}{l}\text { Huang \& } \\
\text { Badurdeen, } 2018\end{array}$ & $\begin{array}{l}\text { TBL, adopted } \\
\text { methodology }\end{array}$ & tested in 1 company & $\begin{array}{c}\text { data available in the } \\
\text { enterprise }\end{array}$ & simple index \\
\hline
\end{tabular}

\footnotetext{
${ }^{3}$ The sum of the papers in research areas is higher than 20, as papers can be related to several research areas.

${ }^{4}$ Paper by Rajnoha, Lesníková and Krajčík.

${ }^{5}$ Paper by Staňková and Zapletal.
} 
Table 2: Results of the analysis of the content of papers according to the specific criteria (continues)

\begin{tabular}{|c|c|c|c|c|}
\hline Marimin et al., 2018 & $\begin{array}{l}\text { without } \\
\text { explanation, } \\
\text { dimensions } \\
\text { established } \\
\text { without further } \\
\text { explanation }\end{array}$ & tested in 1 company & $\begin{array}{c}\text { expert survey - inter- } \\
\text { views and question- } \\
\text { naires }\end{array}$ & simple index \\
\hline $\begin{array}{l}\text { Schrippe \& } \\
\text { Ribeiro, } 2018\end{array}$ & $\begin{array}{l}\text { adopted meth- } \\
\text { odology }\end{array}$ & $\begin{array}{c}\text { tested in } 60 \text { organisa- } \\
\text { tions }\end{array}$ & $\begin{array}{l}\text { secondary data (avail- } \\
\text { able questionnaires) }\end{array}$ & simple indices \\
\hline Jiang et al., 2018 & $\begin{array}{l}\text { review, TBL, } \\
\text { authors' own } \\
\text { research }\end{array}$ & $\begin{array}{l}\text { tested in } 49 \text { companies } \\
\text { for the period of } 2 \text { years }\end{array}$ & $\begin{array}{l}\text { interviewing company } \\
\text { representatives }\end{array}$ & factor analysis \\
\hline Rodrigues et al., 2018 & $\begin{array}{l}\text { TBL, review, } \\
\text { authors' own } \\
\text { research }\end{array}$ & tested in 1 city & $\begin{array}{l}\text { interviewing company } \\
\text { representatives }\end{array}$ & $\begin{array}{c}\text { multi-criteria } \\
\text { decision-making }\end{array}$ \\
\hline $\begin{array}{l}\text { Liern \& } \\
\text { Pérez-Gladish, } 2018\end{array}$ & $\begin{array}{c}\text { adopted } \\
\text { methodology, } \\
\text { dimensions } \\
\text { established } \\
\text { without further } \\
\text { explanation }\end{array}$ & tested in 79 companies & $\begin{array}{l}\text { secondary data (other } \\
\text { indices, financial data) }\end{array}$ & $\begin{array}{c}\text { fuzzy logic }+ \\
\text { multi-criteria } \\
\text { decision-making }\end{array}$ \\
\hline Djekic et al., 2018 & $\begin{array}{l}\text { review without } \\
\text { explanation of } \\
\text { the rules }\end{array}$ & tested in 4 organisations & $\begin{array}{c}\text { company data obtained } \\
\text { by an unspecified } \\
\text { method }\end{array}$ & fuzzy logic \\
\hline $\begin{array}{l}\text { Mansourianfar \& } \\
\text { Haghshenas, } 2018\end{array}$ & $\begin{array}{l}\text { reviews with- } \\
\text { out explanation } \\
\text { of the rules, } \\
\text { TBL }\end{array}$ & tested in 1 city & secondary data & $\begin{array}{c}\text { multi-criteria } \\
\text { decision-making }\end{array}$ \\
\hline $\begin{array}{l}\text { Alderete \& } \\
\text { Bacic, } 2018\end{array}$ & $\begin{array}{c}\text { adopted } \\
\text { methodolo- } \\
\text { gy, review, } \\
\text { dimensions } \\
\text { determined } \\
\text { without further } \\
\text { explanation }\end{array}$ & $\begin{array}{l}\text { tested in } 540 \text { munici- } \\
\text { palities }\end{array}$ & secondary data & factor analysis \\
\hline $\begin{array}{l}\text { Kopacz, Kryzia \& } \\
\text { Kryzia, } 2017\end{array}$ & $\begin{array}{l}\text { TBL, review } \\
\text { without expla- } \\
\text { nation of the } \\
\text { rules }\end{array}$ & tested in heavy industry & secondary data & $\begin{array}{c}\text { multi-criteria } \\
\text { decision-making }\end{array}$ \\
\hline Venturelli et al., 2017 & $\begin{array}{l}\text { review, } \\
\text { authors' own } \\
\text { research }\end{array}$ & tested in 3 companies & $\begin{array}{l}\text { semi-structured inter- } \\
\text { view }\end{array}$ & fuzzy logic \\
\hline
\end{tabular}


Table 2: Results of the analysis of the content of papers according to the specific criteria (continues)

\begin{tabular}{|c|c|c|c|c|}
\hline Kalutara et al., 2017 & $\begin{array}{l}\text { review, TBL, } \\
\text { authors' own } \\
\text { research }\end{array}$ & not tested & $\mathrm{xxx}$ & factor analysis \\
\hline $\begin{array}{l}\text { Azevedo \& } \\
\text { Barros, } 2017\end{array}$ & $\begin{array}{l}\text { TBL, authors' } \\
\text { own research, } \\
\text { adopted } \\
\text { methodologies, } \\
\text { dimensions } \\
\text { established } \\
\text { without further } \\
\text { explanation }\end{array}$ & tested in 25 companies & $\begin{array}{l}\text { secondary data (Sus- } \\
\text { tainibility report) }\end{array}$ & $\begin{array}{c}\text { multi-criteria } \\
\text { decision-making }\end{array}$ \\
\hline $\begin{array}{l}\text { Rajnoha, Lesníková, \& } \\
\text { Krajčík, } 2017\end{array}$ & $\begin{array}{c}\text { adopted } \\
\text { methodology, } \\
\text { dimensions } \\
\text { established } \\
\text { without further } \\
\text { explanation }\end{array}$ & tested in 1 company & $\begin{array}{l}\text { secondary data (enter- } \\
\text { prise data for } 5 \text { years) }\end{array}$ & $\begin{array}{c}\text { multi-criteria } \\
\text { decision-making }\end{array}$ \\
\hline Kılk1ş, 2016 & $\begin{array}{l}\text { adopted meth- } \\
\text { odology }\end{array}$ & tested in 12 cities & $\begin{array}{l}\text { secondary data (from } \\
\text { authorities and agen- } \\
\text { cies) }\end{array}$ & simple index \\
\hline $\begin{array}{l}\text { Staňková \& } \\
\text { Zapletal, } 2016\end{array}$ & $\begin{array}{l}\text { TBL, di- } \\
\text { mensions } \\
\text { established } \\
\text { without further } \\
\text { explanation }\end{array}$ & tested in 3 companies & $\begin{array}{l}\text { secondary data - Inter- } \\
\text { net presentations, CSR } \\
\text { reports, other publica- } \\
\text { tions and research }\end{array}$ & $\begin{array}{l}\text { multi-criteria } \\
\text { decision-making } \\
+ \text { fuzzy logic }\end{array}$ \\
\hline $\begin{array}{l}\text { Janamrung \& Issaraworn- } \\
\text { rawanic, } 2015\end{array}$ & $\begin{array}{l}\text { adopted } \\
\text { methodology, } \\
\text { dimensions } \\
\text { established } \\
\text { without further } \\
\text { explanation }\end{array}$ & tested in 204 companies & $\begin{array}{l}\text { secondary data (annual } \\
\text { reports, data streams) }\end{array}$ & simple index \\
\hline $\begin{array}{l}\text { Amini \& } \\
\text { Bienstock, } 2014\end{array}$ & $\begin{array}{l}\text { adopted meth- } \\
\text { odology, TBL, } \\
\text { dimensions } \\
\text { established } \\
\text { without further } \\
\text { explanation }\end{array}$ & not tested & $\mathrm{xxx}$ & simple index \\
\hline Ngai et al., 2014 & $\begin{array}{c}\text { adopted } \\
\text { methodology, } \\
\text { dimensions } \\
\text { established } \\
\text { without further } \\
\text { explanation }\end{array}$ & not tested & $\begin{array}{c}\text { focus groups, inter- } \\
\text { views }\end{array}$ & $\begin{array}{c}\text { multi-criteria } \\
\text { decision-making }\end{array}$ \\
\hline
\end{tabular}

Source: authors, based on data from the Scopus database ('Scopus' 2018) 
Most of the analysed papers (11 out of 20) used the CSR TBL concept to identify the dimensions (i.e. the economic, environmental, and social dimensions). For establishing the categories (or subcategories, if the categories were further divided), the authors most often used the existing indices/models (which were further supplemented or modified) or reviews - see Table 2, criterion 1: The method of determining dimensions and (sub)categories. The CSR concept itself is not exactly defined and there is no generally accepted standard to follow (see the outputs of the initial study). The choice of the indices or models is very diverse. The authors of the papers do not usually justify their choice, except stating that this is a known index/model, or that the index/model is suitable for the examined area. The methodologies/indices chosen by the authors (see Table 2, criterion 1) are specifically named in table 3 .

Only the authors of two papers are more specific about the process of constructing the index, dimensions, and index categories. For the index construction, Huang and Badurdeen (2018) used the combination of two indices so that the resulting (sub)categories did not overlap and were clear. Schrippe and Ribeiro made an interesting adjustment of the already constructed index. They divided the existing categories into compulsory and compensatory categories based on the assessment of the index categories by a group of experts. The compulsory categories must be fulfilled by organisations at least to some extent in order for them to be considered socially responsible, this does not apply for the compensatory categories (Schrippe \& Ribeiro, 2018).

Table 3: Methodologies chosen for the index construction in the analysed papers

\begin{tabular}{|l|l|}
\hline $\begin{array}{l}\text { The authors constructed their index based on the } \\
\text { mentioned methodologies, indices: }\end{array}$ & The index was constructed in a different, unclassifiable way: \\
\hline $\begin{array}{l}\text { Huang \& Badurdeen, 2018: Process Sustainability } \\
\text { Index and Product Sustainability Index }\end{array}$ & Mansourianfar \& Haghshenas, 2018: predetermined rules \\
\hline $\begin{array}{l}\text { Schrippe \& Ribeiro, 2018: Corporate Sustainabil- } \\
\text { ity Index }\end{array}$ & $\begin{array}{l}\text { Azevedo \& Barros, 2017: content analysis of sustainability } \\
\text { reports }\end{array}$ \\
\hline $\begin{array}{l}\text { Liern \& Pérez-Gladish, 2018: model of the Vigeo } \\
\text { rating agency }\end{array}$ & Staňková \& Zapletal, 2016: beyond the legal framework \\
\hline Djekic et al., 2018: model by Liu a Lai & \\
\hline $\begin{array}{l}\text { Rajnoha, Lesníková, \& Krajčík, 2017: model by } \\
\text { Krajnce and Glaviče }\end{array}$ & \\
\hline K1lk1ş, 2016: SDEWES City Sustainability Index & \\
\hline $\begin{array}{l}\text { Janamrung \& Issarawornrawanic, 2015: from } \\
\text { KLD Rating Data a Corporate Social Responsibili- } \\
\text { ty Guideline of the Corporate Social Responsibili- } \\
\text { ty Institute of the Stock Exchange of Thailand }\end{array}$ \\
\hline $\begin{array}{l}\text { Amini \& Bienstock, 2014: according to the Hart's } \\
\text { natural resource-based view of the firm, TBL and } \\
\text { the zero waste perspective }\end{array}$ \\
\hline $\begin{array}{l}\text { Ngai et al., 2014: adapted Wood's 3P model (prin- } \\
\text { ciples, processes and products) }\end{array}$ \\
\hline
\end{tabular}

Source: authors, based on data from the Scopus database ('Scopus' 2018)

In case when the index (sub)categories resulted primarily from the review - see table 2 , the review was often supplemented by other methods - most often by individual or group interviewing of experts. The number of the interviewed experts ranged from 3 to 7 (Schrippe \& Ribeiro, 2018; Rodrigues et al., 2018; Venturelli et al., 2017). Some authors belonging to this group also state that when determining the (sub)categories, they followed not only the results of the review, but also certain pragmatic motives - their own experience and inventions. For example, Rodrigues et al. (2018) adopted a rule according to which only the category that can be further divided can be considered the category. Kopacz, Kryzia and Kryzia (2017) admit that they chose the content of the categories in such a way that the values were easily identifiable and the total number of included (sub)categories was not too large.

Only three papers from the group of papers using review methods for the identification of (sub)categories also use the factor analyses or their alternatives. The procedure is best described in Kalutara et al. (2017), who identified the individual dimensions and their preliminary categories on the basis of a literature review and enterprise docu- 
ments. The dimensions were subsequently evaluated by 6 selected experts and adapted in order to be relevant to the examined sectors. This way, 67 preliminary influencing factors were identified (Kalutara et al., 2017). The authors then sent a questionnaire to the selected respondents who met several conditions, which ensured that the respondents understood the problem. ${ }^{6}$ The aim was to find out the perceived validity of the individual identified preliminary factors for each dimension. The validity was evaluated on a five-point Likert scale, with the individual points expressed both linguistically and numerically. ${ }^{7}$ Before performing the factor analysis, both the internal consistency of respondents' responses (inter-item reliability) using Cronbach's coefficient $\alpha$ and the validity were calculated. In terms of the validity, the authors verified whether the evaluation of the relevance of factors by 6 experts corresponded to the evaluation of a wider sample of addressed respondents. The weighted arithmetic average was used for this purpose. By performing the factor analysis ${ }^{8}$ on the material of 67 preliminary influencing factors, 18 superior groups that became the index categories were identified (Kalutara et al., 2017) ${ }^{9}$.

As well as Kalutara et al., Jiang et al. wanted the index to accurately measure the social performance of the organisation, and the reliability and validity. ${ }^{10}$ The authors used Cronbach's coefficient $\alpha$ to calculate the reliability. Analysing the validity, they distinguish between the content and construct validity. The content validity is calculated using the correlation coefficient between the indicator and the initial performance score. The construct validity is calculated using the main components method (Jiang et al., 2018). As a result, the authors eliminated some of the preliminary factors set by the study since they did not meet the set values and thus gained the final categories. ${ }^{11,12}$

Alderete and Bacic (2018) also used the factor analysis to create the categories and the entire index. First, they used the main components method and subsequently (as well as Kalutara et al. (2017)) the Varimax method for rotation. Marimin et al. (2018) used a more general alternative to the factor analysis in their research. They used the multidimensional scaling to construct a three-point scale, on which they measured the individual categories (Mono- lingual dictionary).$^{13}$

The last group of authors approached the formulation of (sub)categories in a completely different way than described above. For example, Azevedo and Barros (2017) used the content analysis to examine the sustainability reports of 25 companies over a 16-year period. On the basis of the carried out analysis and taking into account the Global Reporting Initiatives Guidelines and established requirements (categories must be measurable, data must be available and verifiable), the authors formulated the final category (Azevedo, \& Barros, 2017). Staňková and Zapletal (2016), in their turn, picked out only the categories that go beyond the legal obligations of the organisation. Contrarily, Mansourianfar and Haghshenas firstly defined a set of nine rules, on the basis of which they then chose the final form of the subcategories (Mansourianfar \& Haghshenas, 2018). ${ }^{14}$

On the basis of the carried-out analysis, it can be concluded that most of the indices are conceived as aggregated constructs whose structures contain weights. Indices always allow for the possibility of multiple criteria that are thereafter combined with their structure, in which a value in the form of weights is assigned to each newly created category. It is often very difficult to draw a line between the index contents construction and construction of the weights assigned to each part of the index.

On the basis of the carried-out analysis, the authors of this paper created groups of indices that showed the same approaches to their construction - see table 2. Basically, the approaches to the index construction can be divided into four groups.

\section{Simple indices}

The first group does not use weights at all or uses them only at the last stage of the aggregated index construction. This group includes, for example, the index constructed by Ribeiro et al. (2018), which shows the percentage of compliance with the requirements placed on an organisation, or the Schrippe and Ribeiro index (2018) showing how the organisation fulfills the so-called compulsory criteria in percentage $^{15}$ (Schrippe \& Ribeiro, 2018). The dimension

${ }^{6}$ They received 107 responses in total (Kalutara et al., 2017).

7 Strongly disagree (1-1.5), disagree (1.5-2.5), neither agree nor disagree (2.5-3.5), agree $(3,5-4,5)$ strongly agree $(4,5-5,0)($ Kalutara et al., 2017).

8 They chose the Varimax rotation method (Kalutara et al., 2017).

9 The data file containing the overview of all the dimensions, categories, and subcategories is at the authors' disposal. The file was not published for being too extensive.

${ }^{10}$ The questionnaire was completed by 49 companies united in 1 association. Its aim was to find out the data in the individual TBL dimensions (Jiang et al., 2018).

${ }^{11}$ Cronbach's coefficient $\alpha$ is higher than 0,7 , correlation coefficient (content validity) is higher than 0,5 , and the loading between the correlated indicators and the first main component (construct validity) is higher than 0,5 (Jiang et al., 2018).

12-14 The data file containing the overview of all the dimensions, categories, and subcategories is at the authors' disposal. The file was not published for being too extensive. 
value can also be calculated as the ratio of the points obtained per each dimension category to the maximum number of points in the dimension. The final index value is then determined by the arithmetic average of the dimension values (Janamrung, \& Issarawornrawanich, 2015). The index value given by the average of the dimension values is also presented by Huang and Badurdeen (2018), as well as Marimina et al. (2018) and Kılkışe (2016) who use the simple weighting. The idea is to make the index construction as simple as possible and understandable to users, compared to the following indices, which are more sophisticated, more accurate, and therefore, sometimes more difficult to be understood by general public.

2. Indices using the selected multi-criteria decision-making method

The second group uses the multi-criteria decision-making methods, most often the method of analytical hierarchical process, sometimes extended by the unconventional linguistic models and fuzzy logic. To determine the value of each dimension, Azevedo and Barros used the Delf method. The value of each dimension is determined by the sum of the category values that can have a positive or negative impact on the dimension, i.e. a positive or negative value. To aggregate dimensions into the resulting index, the multi-criteria method of decision-making, namely the weighted sum method, the advantage of which is transparency and clarity for the public, was used (Azevedo \& Barros, 2017). Mansourianfar and Haghshenas follow the method of analytical hierarchical process, where, within the pair comparison, experts assess which of the two offered (sub)categories is more important and by how much. The index value is determined by the sum of the weights and normalised values of each category (Mansourianfar \& Haghshenas, 2018). Kopacz, Kryzia, and Kryzia (2017) or Rajnoha, Lesníková, and Krajčík (2017) also used the analytical hierarchical process method. Staňková and Zapletal as well as Liern a Pérez-Gladish (2018) extended the method by the unconventional linguistic models and fuzzy logic.

3. Indices using the unconventional linguistic models and fuzzy logic

The third group uses the unconventional linguistic models and fuzzy logic in the index construction. It uses linguistic terms to introduce the preferences of the decision-maker (Pokorný et al., 2017). Djekic et al. expressed each category on a three-value linguistic scale, which was subsequently converted into numeric values on a scale from 0-100. When aggregating dimensions, each dimension had the same weight (Djekic et al., 2018). Unconventional linguistic models and fuzzy logic, specifically the fuzzy expert system, were also used by Venturelli et al. (2017).

\section{Indices using the factor analysis}

The last group uses the factor analysis (or its analogy - the main components method) in the index construction. Both Kalutara et al. and Alderete a Bacic used it not only to identify categories, but also to reveal the weights. They chose the method of the main components to select the factors. Kalutara et al. presented the way of aggregation as well - the index is calculated as the sum of the values of individual dimensions multiplied by the respective weights (Kalutara et al., 2017). Jiang et al. chose the method of the main components instead of the factor analysis. The resulting index is then given by the product of the sustainable performance score and development coordination degree (Jiang et al., 2018).

When constructing the index, the expert panels are often used for deciding on the categories, dimensions, and weights. The expert panels method is aimed at summarising and synthesis of a wide range of data and information and creating a summarising report, which is a set of recommendations for solving the discussed issue or an overall vision regarding the covered subject. The main task of the expert panel is usually the synthesis of different input data. The method is suitable for solving the highly complex issues (e.g. CSR) requiring knowledge from different disciplines.

\section{Discussion}

The scoping review shows that the indices authors use the form of a case study in a particular organisation to test the indices the most often. The number of the investigated organisations did not exceed 12 in the case of the multiple case studies. The data are obtained primarily from the secondary sources. Only in 3 cases the authors did obtain the index calculation data from interviewing in the organisation. The above-mentioned procedure does not change in the case of larger research samples (from 49 to 204 organisations). The authors most often use the data from the databases, or the information provided on the websites or in reports of the investigated organisations.

Schrippe and Ribeiro's approach, where they collected data for creating an adjusted index directly from the ques-

${ }^{15}$ The dimension value in their model is given by the lowest value of the compulsory category and the final index value is given by the lowest dimension value. The index is therefore based on the idea that poor performance in one compulsory dimension/ category means that an organisation cannot be considered socially responsible. 
tionnaires that the companies had to fill out in order to have a chance to reach the Corporate Sustainability Index of the Brazilian Stock Exchange can serve as an inspiration1. Given that this is a relatively exceptional index, which a maximum of 40 out of the 200 companies with the most liquid shares can reach, the vast majority of the selected companies voluntarily published their answers, which in turn served as a data source for the further research of the authors (Schrippe \& Ribeiro, 2018).

There is no consensus about the method of determining the weights and index construction. Most of the CSR indices are created by using the existing data, which are later variously adjusted according to the expert panels formed according to different criteria.

According to Mansourianfar and Haghshenas, the subcategories must meet the following criteria by being (Mansourianfar \& Haghshenas, 2018):

- relevant to sustainability in its three main dimensions;

- comprehensible to an ordinary citizen;

- transparent in its content and structure - i.e. the user should be able to find out how the final value is calculated;

- foreseeable;

- comparable;

- appropriate for scaling, i.e. measurable on an appropriate spatial and time scale;

- measurable, i.e. repeatedly measured and able to be quantified;

- feasible, i.e. reliable, reasonably priced and

- independent, i.e. independent of each other.

In the carried out scoping review, it was not possible to well-monitor the way the described indices were used. They are explicitly mentioned only in 2 papers. Most of the time, the authors only state that they created their own index based on a review, but they are not specific in what exactly the review contained. If we accept the options described in the introduction to interpret the output data of the indices as nominal, ordinal, and cardinal data, then at first glance it seems possible to create an order of organisations according to the CSR rate by means of the CSR index evaluation. If we consider the resulting indices as ordinal, then we can trace the use, as different forms of rankings within a single index methodology are used. However, taking into account the cardinal data shows that the resulting CSR indices of different methodologies do not determine the real ranking of organisations. This is due to the inconsistency of the construction of the different CSR indices, the diversity of inputs for the evaluation of the CSR indices, and the diversity of profiles of the target evaluated groups of organisations. The CSR index notice value is also affected by the data source processed in the CSR index, the method of evaluating the data in the CSR index, as well as the clarity of the CSR output for the user.
It can be assumed that there is still a number of other ways of constructing and evaluating the CSR indices that are traceable in other scientific databases.

In the process of summarising the outputs of the carried-out research, we face a number of follow-up questions: Is CSR a suitable content for indexing? Can the CSR activities that should be an expression of free will and a specific visibility of the organisation's relations with the society be expressed by the index? What is more relevant for the CSR index evaluating? Are these data obtained from publicly available sources that respondents publish themselves or the process by which an organisation reaches the value of a particular index? Furthermore, the differences in social, i.e. national, religious, regional, legislative frameworks at national levels that change the concept of CSR according to the environment must be taken into account (Bernardová et al., 2018a).

The positive effects of CSR activities on the society are one of the basic characteristics of the CSR concept, and these can only be perceived by the end-users. Maria Gjølberg illustrates this fact in her paper. To address it, she develops 2 indices: one measuring the CSR activities and one measuring the CSR performance in 20 OECD countries. The comparison of results reveals the significant differences between the 20 countries. (Gjølberg, 2009). The issue of approaching the CSR indices in different countries is also discussed by Halkos and Skouloudis (2018), who highlight the interconnection of the global CSR concept and innovative capacity with regard to the national specifics of individual countries.

CSR is a social construct that develops in parallel with the social evolution. This is documented in a timeline of scientifically and practically recognised definitions. In 1954, Bowen defined the CSR as: “... the entrepreneur's obligations to carry out such procedures, to take such decisions or to follow such direction of conduct as desirable in terms of the objectives and values of the society.' The 2001 Definition of the European Commission defines the CSR as follows: "... describe it as a concept whereby companies integrate social and environmental concerns in their business operations and in their interaction with their stakeholders on a voluntary basis...."(Commission of the European Communities, 2001). The UN states that: „Corporate sustainability is imperative for business today - essential to long-term corporate success and for ensuring that markets deliver value across society. To be sustainable, companies must do five things: Foremost, they must operate responsibly in alignment with universal principles and take actions that support the society around them. Then, to push sustainability deep into the corporate DNA, companies must commit at the highest level, report annually on their efforts, and engage locally where they have a presence." (UN, 2014, p. 7) Rasche's et al., (2017) definition says: "CSR policy acts as a self-regulatory mechanism by which the company monitors and ensures its 
active compliance with legal spirit, ethical standards and national or international standards." The concept of CSR is being transformed, however, the ethical nature of entrepreneurs' responsibility towards the society remains the same. Responsibility as an individual response to the needs of others is elaborated in the paper by Lévinas. The author emphasises the primacy of ethical (moral) values over any thinking, knowledge and people's actions (Lévinas, 2009, p. 123). In terms of CSR, this means: understanding the needs of the society and taking into consideration the societal needs in entrepreneurship; the ability to communicate with all the stakeholders; the ability to orientate in the structure and functioning of the company; the ability to estimate the consequences of one's own conduct; and the ability to see one's own role in passing on the values to the future generations.

\section{Conclusion}

The aim of the paper was to find out how the indices that evaluate the socially responsible behaviour of organisations are created. The reason is to evaluate their usability for SMEs that account for around $99 \%$ of active entrepreneurial entities in the EU (European Parliament, 2020).

The indices are a well-established tool of the CSR measurement. Approaches to their construction are of different level of complexity, which subsequently manifests itself in the level of their comprehensibility. The CSR methodologies using other than simple mathematical procedures are complicated to interpret. Indices using the linguistic models and fuzzy logic are intended to make the value data more effective by using the knowledge and experience of the "experts". In the data processing, they do not use the mathematical, but the linguistic models. But even these indices do not always give us the ability to understand the logic of their construction for SMEs.

In the case of SMEs, the use of the CSR index according to the above-mentioned construction methods seems problematic. SMEs cannot employ the CSR experts or employees understanding the complex descriptions of the CSR indices construction (see indices using the factor analysis, indices using the multi-criteria decision-making methods, indices using the unconventional linguistic models and fuzzy logic) (Bernardová et.al., 2018b). SMEs also do not often produce the data which the indices based on the secondary data processing are drawn from. The indices described in the simple index group are mainly applicable to SMEs.

Limitations of the research and ethical aspects of the study:

The carried-out research has several limitations to be taken into account when interpreting the results. The scoping review was conducted within one database and only in the selected period of 2014-2018. Therefore, extending the review for additional databases and time periods could potentially change the results. It should be also noted that the assessment of the relevance of the papers to the study question was carried out by one researcher, which increases the level of subjectivity of the selection.

\section{Acknowledgements}

This article is dedicated to the Project No. TL02000336: Corporate Social Responsibility Index under the Éta 2 TAČR Program financed by the Technology Agency of the Czech Republic.

\section{Literature}

Adel, C., Hussain, M., Mohamed, E., \& Basuony, M. (2019). Is corporate governance relevant to the quality of corporate social responsibility disclosure in large European companies? International Journal of Accounting \& Information Management, 27(2), 301332. https://doi.org/10.1108/IJAIM-10-2017-0118

Alderete, M.V., \& Bacic, M.J. (2018). Local Productive Arrangements and local development in non-metropolitan municipalities of Sao Paulo, Brazil. Cuadernos de Gestión, 18 (1), 103-124. http://doi.org/10.5295/ cdg. $150561 \mathrm{ma}$

Arksey, H., \& O’Malley, L. (2005). 'Scoping Studies: Towards a Methodological Framework'. International Journal of Social Research Methodology. 8(1), 19-32. https://doi.org/10.1080/1364557032000119616

Azevedo, S., \& Barros, M. 2017. The Application of the Triple Bottom Line Approach to Sustainability Assessment: The Case Study of the UK Automotive Supply Chain. Journal of Industrial Engineering and Management, 10(2): 286. https://doi.org/10.3926/jiem.1996.

Bernardová D., Ivanová, K., \& Fink, M. (2018a). CSR: země vzniku, země rozvoje, země aplikace [CSR - Countries of Origin, Countries of Development, Countries of Application]. In Horáková, N., ed. Sociologické výzvy ve středoevropském kontextu: 8. československé sociologické dny v Ostravě 15. 11. 2017 [Sociological challenges in the Central European context: 8th Czech-Slovak Sociological Days in Ostrava 15. 11. 2017]. Ostrava: Ostravská univerzita.

Bernardová D., Ivanová, K., \& Kubicová, J. (2018b). Společenská odpovědnost organizacía její význam pro rozvoj region. [Corporate Social Responsibility and its Importance for the Development of the Region]. In Jílková, E. et al. Hospodárská politika a regionální rozvoj [Economic Policy and Regional Development] (pp. 148-176). Olomouc: Moravská vysoká škola Olomouc

Bowen. H. R. (1953). Social Responsibilities of the Businessman. New York: Harper \& Row. 
Chadegani, Arezoo Aghaei, Hadi Salehi, Melor Md Yunus, Hadi Farhadi, Masood Fooladi, Maryam Farhadi, \& Nader Ale Ebrahim (2013.) A Comparison between Two Main Academic Literature Collections: Web of Science and Scopus Databases'. Asian Social Science. 9 (5), 18-26. https://doi.org/10.5539/ass.v9n5p18

Collison, D., Cobb, G., Power, D., \& Stevenson, L. (2009). FTSE4Good: exploring its implications for corporate conduct. Accounting, Auditing \& Accountability Journal, 22(1), 35-58. https://doi.org/10.1108/09513570910923006

Commission of the European Communities. (2001). Green Paper. Promoting a European Framework for Corporate Social Responsibility. Retrieved January 22, 2019 from https://ec.europa.eu/commission/presscorner/detail/en/DOC 01 9

Eldomiaty, T., Soliman A., Fikri A., \& Anis, M. (2016). The financial aspects of the Corporate Responsibility Index in Egypt: A quantitative approach to institutional economics. International Journal of Social Economics, 43(3), 284-307.

Elkington, J. (2013). Enter the Triple Bottom Line. In: The Triple Bottom Line, Does It All Add Up?: Assessing the Sustainability of Business and CSR. London: Earthscan

European Commission (2015). Awareness-raising questionnaire. Retrieved December 30, 2018, from https:// ec.europa.eu/docsroom/documents/10369/attachments/1/translations/en/renditions/pdf

European Commission. (2011). Communication from The Commission to The European Parliament, The Council, The European Economic and Social Committee and The Committee of The Regions: A renewed EU strategy 2011-14 for Corporate Social Responsibility. Retrieved December 18, 2018 from https://eur-lex. europa.eu/legal-content/EN/TXT/PDF/?uri=CELEX:52011DC0681\&from $=\mathrm{EN}$

European Commission. (2009). The governance challenge for knowledge policies in the Lisbon Strategy: Between revolution and illusion. Luxembourg: Office for Official Publications of the European Communities. Retrieved December 18, 2018, from http://ec.europa.eu/ invest-in-research/pdf/download en/kin123469enc web.pdf)

European Parliament (2020). Small and medium-sized enterprises. In Fact Sheets on the European Union. Retrieved January 20, 2020 from https://www.narodniportal.cz/legislativa/narodni-akcni-plan-pro-byznysa-lidska-prava-na-obdobi-2017-2022/https:/www.europarl.europa.eu/ftu/pdf/en/FTU_2.4.2.pdf

European Parliament (2014). Directive 2014/95/EU: Non-financial reporting. Retrieved December 18, 2018 from https://eur-lex.europa.eu/eli/dir/2014/95/oj

Fink, M., Ivanová, K., Bernardová, D., Arkhangelska, T., \& Kašparová, K. (2020). Social Responsibility ETA Index 2019. International Journal of Curriculum and Instruction, 12 (Special Issue), 50-65. Retrieved Feb- ruary18, 2020, from https://files.eric.ed.gov/fulltext/ EJ1245281.pdf

Gjølberg, M. (2009). Measuring the immeasurable?: Constructing an index of CSR practices and CSR performance in 20 countries. Scandinavian Journal of Management. 25(1), 10-22. http://doi.org/10.1016/j. scaman.2008.10.003

Government of the Czech Republic (2017). National Action Plan for Business and Human Rights 2017-2022. Retrieved January 18, 2020 from https://www.narodniportal.cz/legislativa/narodni-akcni-plan-pro-byznys-alidska-prava-na-obdobi-2017-2022/

Halkos G., \& Skouloudis A. (2018). Corporate social responsibility and innovative capacity: Intersection in a macro-level perspective. Journal of Cleaner Production, 182, 291-300. https://doi.org/10.1016/j.jclepro.2018.02.022

Harzing, A.W., \& Alakangas, S. (2016). Google Scholar, Scopus and the Web of Science: A Longitudinal and Cross-Disciplinary Comparison. Scientometrics. 106(2), 787-804. https://doi.org/10.1007/s11192-0151798-9

Hawn, O., Chatterji, A. K., \& Mitchell, W. (2018). Do investors actually value sustainability? New evidence from investor reactions to the Dow Jones Sustainability Index (DJSI). Strategic Management Journal, 39 (4), 949-976. http://doi.org/10.1002/smj.2752

Huang, A., \& Badurdeen, F. (2018). Metrics-Based Approach to Evaluate Sustainable Manufacturing Performance at the Production Line and Plant Levels. Journal of Cleaner Production, 192, 462-76. https://doi. org/10.1016/j.jclepro.2018.04.234

Janamrung, B., \& Issarawornrawanich, P. (2015). The Association between Corporate Social Responsibility Index and Performance of Firms in Industrial Products and Resources Industries: Empirical Evidence from Thailand. Social Responsibility Journal, 11(4), 893903. https://doi.org/10.1108/SRJ-11-2013-0141

Janik, B., \& Bartkowiak, M. (2015). The comparison of socially responsible indices in Central and Eastern Europe. International Journal of Environmental Technology \& Management, 18(2), 153-169.

Jiang, Qiuhong, Zhichao Liu, Weiwei Liu, Tao Li, Weilong Cong, Hongchao Zhang, \& Junli Shi. (2018). A Principal Component Analysis Based Three-Dimensional Sustainability Assessment Model to Evaluate Corporate Sustainable Performance. Journal of Cleaner Production, 187, 625-37. https://doi.org/10.1016/j. jclepro.2018.03.255

Kalutara, Pushpitha, Guomin Zhang, Sujeeva Setunge, \& Ron Wakefield. 2017. Factors That Influence Australian Community Buildings' Sustainable Management. Engineering, Construction and Architectural Management, 24 (1), 94-117. https://doi.org/10.1108/ECAM$10-2015-0158$

Kilk1ş, Ş. (2016). Sustainable Development of Energy, Water and Environment Systems Index for Southeast 
European Cities, Journal of Cleaner Production, 130, 222-34. https://doi.org/10.1016/j.jclepro.2015.07.121

Kopacz, M., Kryzia, D \& Kryzia, K. (2017). Assessment of Sustainable Development of Hard Coal Mining Industry in Poland with Use of Bootstrap Sampling and Copula-Based Monte Carlo Simulation. Journal of Cleaner Production, 159, 359-73, https://doi. org/10.1016/j.jclepro.2017.05.038

Leipziger, D. (2003). The corporate responsibility code book. Sheffield: Greenleaf Publishing.

Lévinas, E. (2009). Etika a nekonečno [Ethics and Infinity]. Praha: Oikoymenh

Liern, V., \& Pérez-Gladish, B. (2018). Ranking Corporate Sustainability: A Flexible Multidimensional Approach Based on Linguistic Variables. International Transactions in Operational Research, 25(3), 1081-1100. https://doi.org/10.1111/itor.12469

Mansourianfar, M. H., \& Haghshenas, H. (2018). Micro-Scale Sustainability Assessment of Infrastructure Projects on Urban Transportation Systems: Case Study of Azadi District, Isfahan, Iran. Cities, 72,149-59. https://doi.org/10.1016/j.cities.2017.08.012

Marimin, Darmawan, M. A., Widhiarti, M. P., \& Teniwut, Y. K. (2018). Green Productivity Improvement and Sustainability Assessment of the Motorcycle Tire Production Process: A Case Study. Journal of Cleaner Production, 191, 273-82. https://doi.org/10.1016/j. jclepro.2018.04.228

Peršič, A., \& Markič, M. (2013). The Impact of Socially Responsible Reporting on Successful Corporate Operations. Organizacija, 46, 47-54. https://doi. org/10.2478/orga-2013-0007

Peters, M. D. J., Godfrey, C.M, Khalil, H., McInerney, P., Parker D., \& Baldini Soares, C. (2015). Guidance for Conducting Systematic Scoping Reviews. International Journal of Evidence-Based Healthcare. 13 (3), 14146. https://doi.org/10.1097/XEB.0000000000000050

Pinillos, A., A., Fernández-Fernández, J. L., \& Fernández Mateo, J. (2018). A critical review of the Corporate Governance dimension in the Sustainability Indexes questionnaires. Revista de Comunicación, 17 (2), 9-40. https://doi.org/10.26441/RC17.2-2018-A1

Pokorná, D. (2012). Koncept společenské odpovédosti: obsah, podstata, rozsah [Concept of Social Responsibility: Content, Basis, Scope]. Olomouc: Univerzita Palackého

Pokorný, M. et al. (2017). Soft-Computing Technologies in economics expert Systems. In Ryan, D. ed., Expert systems: Design, Applications and Technology (pp. 1-58). New York: Nova Science Publishers

Rajnoha, R., Lesníková, P., \& Krajčík, V. (2017). Influence of Business Performance Measurement Systems and Corporate Sustainability Concept to Overall Business Performance: "Save the Planet and Keep Your Performance". E+M Ekonomie a Management, 20 (1), 111-128. https://doi.org/10.15240/tul/001/2017-1-008

Rasche, A., Morsing, M., \& Moon, J. (eds.). (2017). Cor- porate Social Responsibility: Strategy, Communication, Governance. Cambridge: Cambridge University Press.

Rita, D.I.G., Ferreira, F.A.F., Meidutè-Kavaliauskienė, I., Govindan, J., \& Ferreira, J.J.M. (2018). Proposal of a green index for small and medium-sized enterprises: A multiple criteria group decision-making approach. Journal of Cleaner Production, 196, 985-996. https:// doi.org/10.1016/j.jclepro.2018.05.275

RobecoSAM. (2018). Industry Leaders 2018. Retrieved December 20, 2018, from https://www.robecosam. com/csa/csa-resources/industry-leaders.html

Rodrigues, A.P. et al. (2018). Developing Criteria for Performance Assessment in Municipal Solid Waste Management. Journal of Cleaner Production, 186, 748-57. https://doi.org/10.1016/j.jclepro.2018.03.067

Schrippe, P., \& Ribeiro, J. L. D. (2018). Corporate Sustainability Assessment Heuristics: A Study of Large Brazilian Companies. Journal of Cleaner Production, 188, 589-600. https://doi.org/10.1016/j.jclepro.2018.02.232

Slaper, T. F., \& Hall, T. J. (2011). The Triple Bottom Line: What Is It and How Does It Work? The Indiana Business Review, 86 (1), 4-8. Retrieved January 14, 2019, from http://www.ibrc.indiana.edu/ibr/2011/spring/ pdfs/spring2011.pdf

Staňková, Š., \& Zapletal, F. (2016). Assessment of Corporate Social Responsibility Using Fuzzy Analytic Hierarchy Process. Scientific Papers of the University of Pardubice, Series D: Faculty of Economics and Administration, 2016 (23), 142-54.

United Nations (2019). Micro-, Small and Medium-sized Enterprises Day 27 June. Retrieved March 24, 2019, from https://www.un.org/en/events/smallbusinessday/

United Nations (2014). United Nations Global Compact. UN. Retrieved March 24, 2019, from https:// www.globalcompact.de/wAssets/docs/Nachhaltigkeits-CSR-Management/un global_compact guide_to_corporate_sustainability.pdf

United Nations (2013). Economic and Social Council Explores Integration of Three Sustainable Development Pillars - Economic, Social, Environmental - to Achieve 'Triple Win' Solutions.Meetings Coverage \& Press Releases. Retrieved January 24, 2019, from https:// www.un.org/press/en/2013/ecosoc6574.doc.htm

Venturelli, A., Caputo, F., Leopizzi, R., Mastroleo, G., \& Mio, C (2017). How Can CSR Identity Be Evaluated? A Pilot Study Using a Fuzzy Expert System. Journal of Cleaner Production, 141, 1000-1010. https://doi. org/10.1016/j.jclepro.2016.09.172

Yang Wen-Tao, Zhu Xiang-Dong, \& Nie Zhong-Ying. (2016). Research on evaluation index system of small and medium size enterpises in engineering machinery industry from social responsibility perspective. Journal of the Balkan Tribological Association, 22 (2A-II), 2108-21234. 
Dana Bernardová, Ph.D. is an expert assistant at the Department of Social Sciences and Law, Moravian Business College Olomouc, Olomouc, Czech Republic. Her research focuses on the CSR, HR management, soft skills. She participates in research projects, teaches, conducts soft skills training, and leads project CSR teaching in direct co-operation with SMEs.

Klára Kašparová, Ph.D. is an associate professor at the Department of Corporate Economy, Faculty of Economics and Administration, Masaryk University, Brno, Czech Republic. Her research focuses on the CSR, marketing, marketing communication and marketing research. She participates in the research projects, teaches, and publishes in marketing and CSR.

Martin Fink Mgr. is an expert assistant at the Department of Social Sciences and Law, Moravian Business College Olomouc, Olomouc, Czech Republic. He deals with the CSR, the issue of quality of life and QMS (ISO 9001), teaches CSR and communication skills, and participates in project focused on teaching of CSR in collaboration with regional SMEs.
Kateřina Ivanová, Ph.D. is an associate professor and a temporarily entrusted Vice-Rector for Science, Research and Development; the Associate Professor at the Department of Social Sciences and Law, Moravian Business College Olomouc, Olomouc, Czech Republic. She focuses on the ethical foundations of social responsibility and methodology of sociological research for business practice, conducts scientific research projects, and teaches business ethics, methodology.

Tetiana Arkhangelska, Ph.D. is a Department Manager, senior lecturer at the Department of Social Sciences and Law, Moravian Business College Olomouc, Olomouc, Czech Republic. She focuses on the corporate social responsibility, management of commercial activities abroad, comparative and gender linguistics, teaches and publishes in the field of CSR, Ethics and CSR of small and medium-sized businesses as well as management of commercial activities. 